\title{
頭蓋内原発悪性リンパ腫の母子発生例
}

\author{
池田 正人·石倉 彰・小暮祐三郎
}

\section{Familial Primary Intracranial Malignant Lymphoma}

\author{
Masato IKeDA, Akira IshIKurA and Yuzaburo KoGURE \\ Department of Neurosurgery, Kanazawa National Hospital, Kanazawa
}

\begin{abstract}
A 76-year-old female developed depression and loss of appetite. On admission, in June of 1987, she was disoriented. Computed tomography (CT) revealed enhanced masses without perifocal edema in the cerebellar vermis and left occipital lobe. The cerebellar tumor was subtotally removed through a suboccipital craniectomy. Histological examination disclosed malignant lymphoma of the diffuse, large cell type. The patient underwent postoperative irradiation, and no other tumors were detected by whole-body CT or gallium scans. Her 51-year-old son had been admitted to another hospital in April of 1987, with complaints of depression and change in mental status. Neurological examination revealed right hemiparesis, and CT demonstrated an enhanced left frontal paraventricular mass and severe perifocal edema. The histological diagnosis was malignant lymphoma, and the patient received postoperative irradiation and chemotherapy. A few cases of familial extracranial malignant lymphoma have been described. However, to the authors' knowledge, this is the first reported occurrence of familial primary intracranial malignant lymphoma.
\end{abstract}

Key words: familial malignant lymphoma, brain neoplasms

\section{I はじめに}

頭蓋内原発悪性リンパ腫は脳腫瑒のなかでもまれな腫瘍 とされ，本邦において子全脳腫瘍の $0.9 \%$ と報告されてい る10， しかし，最近ではCT scanの普及による診断技術 の進歩に加之，缄器移植に伴 5 免疫抑制剂の使用 ${ }^{13}$, 故射 線の影響18)などにより発生そのものが増加してきていると 言われている，悪性リンパ腫の病因は明らかにされていな いが，発生要因として免疫不全，低栄養状態，ウイルス感 染などが考えられている．最近我々は，母子に活济同時期 に発生した頭蓋内原発悪性リンパ腫の症例を経験したので 報告寸る。

\section{II 症例}

<症例 $1>76 才$ 才, 女性（〈症例 $2>0$ 母）

主訴：抑万つ状態，食欲不振
既往歴：特記すべきことなし

現病歴：出生·在住ともに富山県であり，生来健康であ った．1987年3月，転倒して右肩を脱臼し，他院に入院加 療していたが，入院中に抑らつ状態，不眠，食欲不振が出 現し徐々に増強してきた。さらに，妄想および夜間せん妄 も出現してきたため，6月 1 日当院神経科に入院した。頭 部 CT scan で異常が認められたため，6月26日当科に転科 した。

入院時所見：全身表在りンパ節の腫脹はなく，肝脾腫も なかった，神経学的には，失見当識，両側下肢筋力低下， 両上肢笳硬直を認めた。

入院時検查所見：検血，検尿に異常なし．血液生化学的 険查では，総蛋白 $7.7 \mathrm{~g} / \mathrm{d} l$, aib. $62.0 \%, \alpha_{1}-$ glob. $3.7 \%, \alpha_{2}$ glob. $10.5 \%, \beta$-glob. $7.1 \%, \gamma$-glob. $16.7 \%, \mathrm{~A} / \mathrm{G} 1.63$, IgG $1847 \mathrm{mg} / \mathrm{d} l$, IgA $259 \mathrm{mg} / \mathrm{d} l$, IgM $408 \mathrm{mg} / \mathrm{d} l$ と, IgG 拈よび IgMが高值のほかは特に異常はなかった。ッベルクリン

Address reprint requests to: M. Ikeda, M.D., Department of Neurosurgery, Kanazawa National Hospital, 3-1-1 Ishibiki, Kanazawa 920.

受稿 1988 年 3 月28日 受理 1988年 6 月15日 

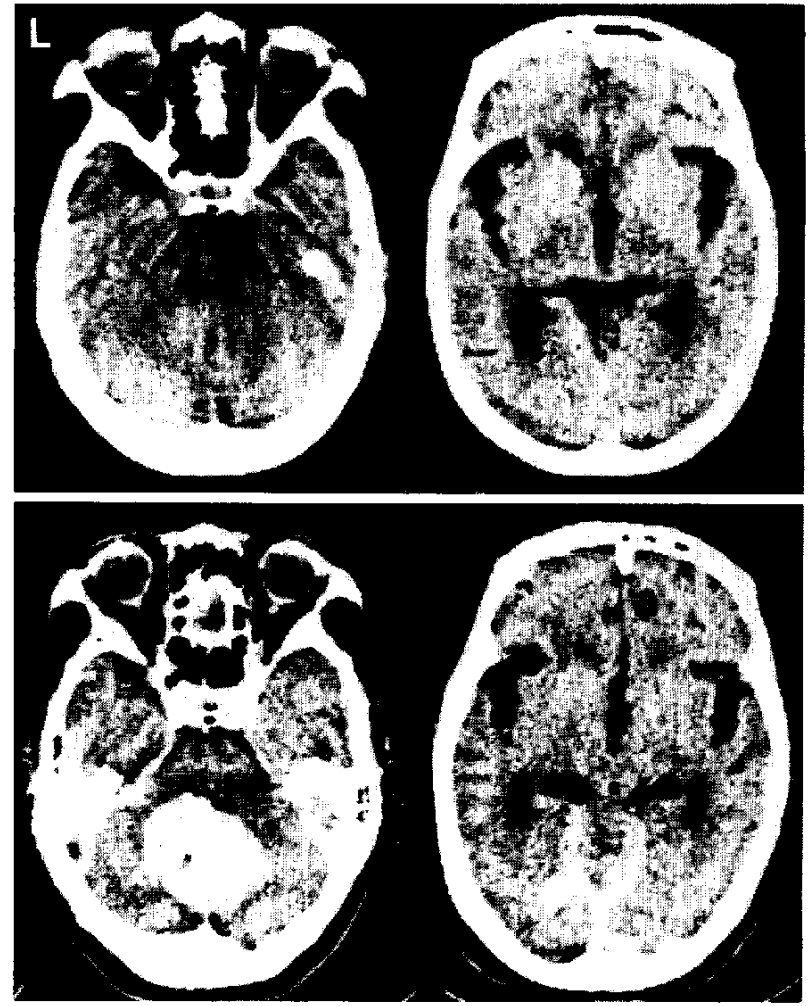

Fig. 1 Case 1. upper: Plain computed tomography (CT) scan, showing an isodense mass in the vermis compressing the fourth ventricle, lower: The mass exhibited homogeneous enhancement. Another enhanced mass can be seen in the left occipital lobe.
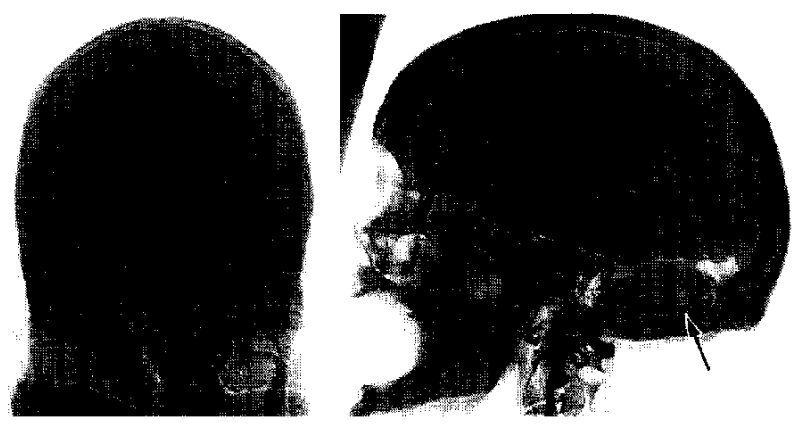

Fig. 2 Gase 1. Left vertebral angiograms, anteroposterior (left) and lateral (right) views, revealing no tumor stains or abnormal vessels. The inferior vermian branch of the left posterior inferior cerebellar artery (arrow) is stretched and displaced toward the inner table of the occipital bone.

反応は陰性であった，髄液検査では，䯣夜圧 $60 \sim 40 \mathrm{~mm}$ $\mathrm{H}_{2} \mathrm{O}$ ，細胞数 $25 / 3 / \mathrm{mm}^{3}(\mathrm{~N} 3, \mathrm{Ly} 22)$, 総蛋白 $149.4 \mathrm{mg} / \mathrm{d} l$, 糖 $49 \mathrm{mg} / \mathrm{d} l, \mathrm{Cl} 118 \mathrm{mEq} / l$ であった。

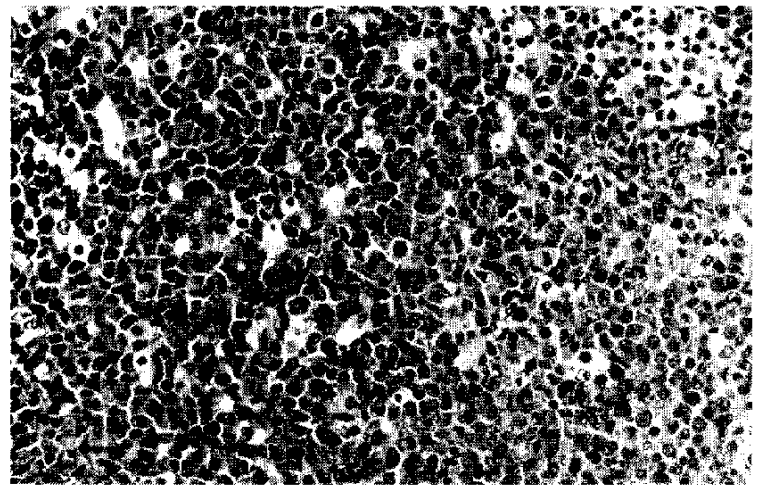

Fig. 3 Case 1. Photomicrograph of the surgical specimen, showing diffuse proliferation of large lymphoid cells and scattered mitoses. HE stain, $\times 100$.

神経放射線学的所見：単純 CT で小脳虫部にやや高吸収 のass を認め，第四脳室の变形偏位，四丘体槽の変形を 認めた，周囲の浮腫は著明ではなかった。 また造影 CTで は注ぼ均一飞增強される mass が存在し，さらに左後頭莱 にも增強像を認めた(Fig. 1)。左椎骨動脈撮影では，腫瘍 陰影や異常血管は認められず，後下小脳動脈 inferior vermian branch の後方への圧排進展が認められた(Fig. 2)。

手術所見：1987年 7 月 1 日，後頭下開頭に上り小脳虫部 を見る上暗赤色の腫瘍があり，周囲との境界は不鮮明であ った，腫瘍を亜全摘し，手術を終了した。

組織学的所見：HE 染色では，大型異型 lymphoid cell の 漂漫性增殖を示し， mitosis 多多数みられた(Fig. 3)。鍍銀 染色で恃，細い好銀性線維が血管周用にリング状に配列し ている所見がみられた。また, PAP 法では lymphocyte common antigen 㧊よびモノクローナル抗ヒト B 細胞抗体 陽性であり，悪性リンパ腫, diffuse, large cell type, B cell type と診断された。

術後経過：7月 8 日上り放射線寮法定開始し，全脳照射 で計40 Gy 照射した，10 Gy 照射時の GT では，腫瘍は 消失していた，放射線照射終了徭も腫湯の再発は認めてい ない，術後 Ga scan およびX 線 CTにて全身の検索を行 ったが，他の部位に腫瘍は認められなかった。また抑らっ 状態や食欲不振も徐々汇軽快し，現在リハビリ中である。 <症例 2 > 51才, 男性 (〈症例 1〉の次男)

主訴：抑らつ状態，人格变化

既往歴および家族歴：特記すべきことなし

現病歴：富山県で出生し成人になるまで在住していた が，成人以後は東京在住で西った。1987年 1 月頃より食欲 不振が出現し，徐々に増悪した。 4 月頃より抑うつ状態打 よび人格変化が出現し, 突然の嘔吐も認めるよらになり, 
4 月20日5つ病の診断で東京慈恵会医科大学精神科に入院 した，入院時，右上肢運動障害を指摘され，CT scanを施 行したところ左前頭葉に腫瘍を疑われ，4月24日脳神経外 科汇転科した。

入院時所見：右不全片麻痺

神経放射線学的所見：単純 CT では，左前頭葉内に側脳 室前角に接して等吸收の董瘍を認め, 周囲に強い浮腫を伴 っていた，造影 CTでは，腫湯ははぼ均一に増強された (Fig. 4). 左頸動脈撮影では腫瘍陰影》異常血管は認めら れず，ンルビウス三角の上辺の下方压排を認めるのみであ った(Fig. 5).

手術所見：1987年 5 月 8 日，手術が施行された。腫瘍と 脳実質との境界は不鮮明で，亜全摘にて手術を終了した。

組織学的所見：血管周囲汇中型異型リンパ球の強い,増殖 と浸潤が認められ，悪性リンパ腫と診断された（Fig. 6)。 なお， cell typeは不明で西った。

術後経過：術後 $50.4 \mathrm{~Gy}$ の放射線療法, お。び adriamycin, cyclophosphamide, vincristin, prednisolone 䎸る化

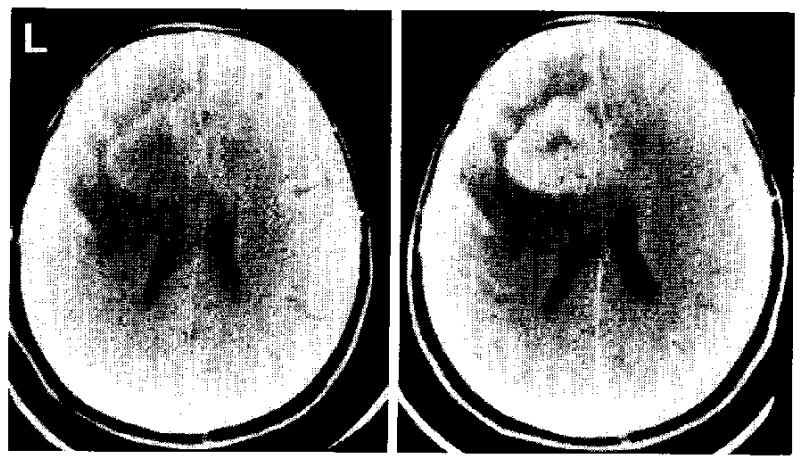

Fig. 4 Case 2. Plain (left) and enhanced (right) CT scans, showing the left frontal paraventricular tumor and severe perifocal edema.
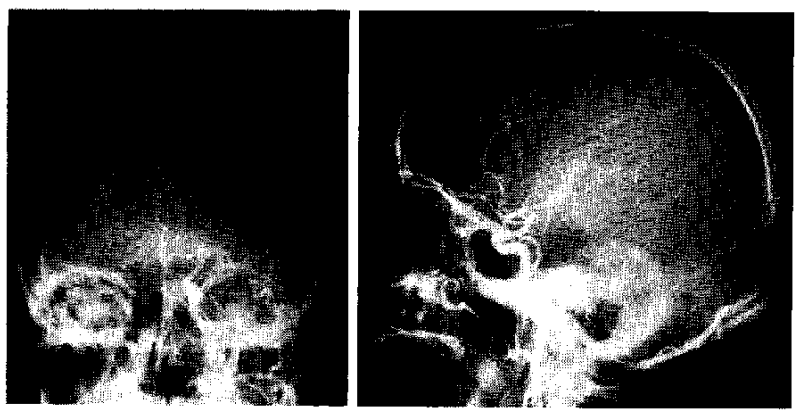

Fig. 5 Case 2. Left carotid angiograms, anteroposterior (left) and lateral (right) views, revealing depression of the upper boundary of the sylvian triangle.

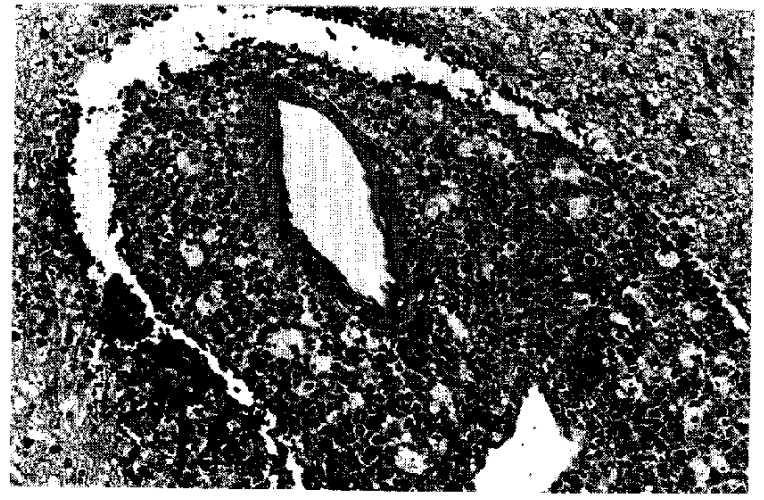

Fig. 6 Case 2. Photomicrograph of the surgical specimen, demonstrating perivascular proliferation of lymphoid cells. HE stain, $\times 60$.

学療法が行われた，術後のCTでは再発恃認められず，全 身検索でも他の部位にリンパ腫は検出されなかった。

\section{III 考察}

頭蓋内原発悪性リンパ腫の好発年齢は40〜60才台であ り，男性に多い傾向にある．頭蓋内生六進症状，運動障害 などの局所症状，精神障害や痴呆で発症することが多く， 臨床症状は非特異的であり診断に苦慮することが多い，症 状は亜急性に進行することが多(、3,8,9)，我々の症例ては，

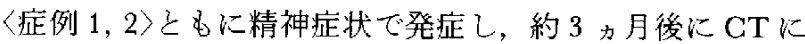
て発見されている。

CT 所見は，等吸収からやや高吸収で辺縁明瞭であり， 造影剂にて均一に增強され，周囲の浮腫は高度のものから 軽度のもの末でさまざまであるとの報告が多い7,11)。束 た，皮質の病変は境界が鮮明で浮腫や压排は少なく均一に 増強されるが，白質の病変は境界不鮮明で浮腫や压排は強 〈不均一に增強されるとの報告もある16)。症例 1〉では， 小脳虫部拉よび左後頭葉ともに均一に増強され，周团の浮 腫は軽度であったまたく症例 2〉では，腫瘍は側脳室前角 に接した白質に存在し，高度の浮連を伴っていた。

脳血管撮影の所見としては，無血管野として描出される ことが多いと報告されている゙．しかし， early venous fill-

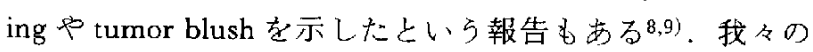
症例では，異常血管や腫瘍陰影は認められず，無血管野よ して描出された。

治療に関しては，頭蓋內悪性りンパ腫は放射線感受性が 高く放射線療法が奏効すると言われている 術扣よび放射線療法が主流々なっており，杂れに化学療法 を併用していくことが多い上らである。初発から死亡まで の期間は, 未治療例では平均 3.3 力, 手術施行例では平 
均4.6力月，手術㞠法扣よび放射線療法併用例では平均 15.2 力と報告されている3!。我々の症例ではいずれる手 術により病理診断がなされ，〈症例 1〉ではdiffuse, large cell type と診断され, cell type はB cell typeであり，〈症 例 2〉では cell type は不明であっだ、術後放射線療法およ び化学療法が施行され，腫瘍は消失し，現在のところ再発 憝められない。

頭蓋内原発覀性りンパ腫は，本邦脳腫瘍全国集計調䍒報 告によると全脳腫瘍の $0.9 \%{ }^{10)}$ とまれな腫瘍であるが，近 年免疫抑制剤の投与なとにより発生自体が増加してきたと され，注目されている。悪性りンパ腫の病因については， 最近成人 $\mathrm{T}$ 細胞 リンパ腫白血病 (ATL)がヒト成人 $\mathrm{T}$ 細胞 白血病ウイルス (HTLV-1)の感染によるものとして注目 されている(2,17)が，他のリンハ腫に関しては病因が明らか にされていない，先天性免疫不全症候群に伴与覀性リンハ 腫の多発2や，近年AIDS 患者に頭蓋内原発悪性りンパ腫 の発生が報告されている14 。また，堅缄移植を受けた患者 に脳原発悪性リンパ腫が発生する例が多いとの報告もあ $ろ^{13)}$. 免疫抑制剂の使用による慢性の免疫不全状態に加点 移植缄器の抗原性の持続的な刺激が加わって悪性リンパ腫 が発生しやすくなり，さらにウイルス感染も関与している のではないかと考えられている6,8).今回の症例では，い ずれも免度不全を示すよらな所見は認められなかった。

家族内発生例に関しては，ATLの垂直感染例や，九州 地方で悪性リンパ腫の家族内発生例が報告されている4). しかし，我々の症例の上らな頭蓋内原発悪性りンハ腫の母 子例は，我々が調べえた限りでは報告がない，ATLの場 合，比較的発生頻度の低い地域での患者が発生頻度の高い 地域の出身であることが多いとされ15)，別の地域に生活し ていた父娘が同時に発症した例5)報告されて招り，今回 の症例に兆いても2人現在異なった地域に生活している が，その発生にはなんらかの関連性があるのではないかと 思われた。

以上，母子にほぼ同時に発生した頭蓋内原発悪性りンパ 腫の 2 例を経験し，その発生要因，家系内発生について文 献的考察を加えて報告した。

稿を終えるに当り，〈症例 2〉に関する貴重な資料を提供してく だいました東京慈恵会医科大学脳神経外科 中村紀夫教授およ び前原成浩 先生に深謝致します。

本論文の要旨は，第25回北陸脳神経外科集談会(1987年 9 月, 富山)に枕いて発表した。

\section{文献}

1) Cassady JR, Wilner HI: The angiographic appearance of intracranial sarcomas. Radiology 88: 258-263, 1967

2) Gatti RA, Good RA; Occurrence of malignancy in immunodeficiency diseases. Cancer 28: 89-98, 1971

3) Henry JM, Heffner RR Jr, Dillard SH, Earle KM, Davis RL: Primary malignant lymphomas of the central nervous system. Cancer 34: 1293-1302, 1974

4) 市丸道人: 家系内発生. 豊島久真男, 高月 清(編). 図説 臨床(癌)シリーズ No. 9, ATL (成人 T 細胞白血病). 東京, メジカルビェ一社, 1986, pp 72-79

5）久保明美，那須 芳，北 堅吉，福原資郎，笹田昌孝，錦 織 優, 内野治人, 中村 徹: 父娘が同時に発症したと思わ れる成人 $\mathrm{T}$ 細胞りンハ腫の一症例。日網内系会誌 $22 ； 3$ ， 1982 (抄録)

6) 熊西敏郎，古賀 誠，小川 宏，中村志夫，生田房弘， 小宅 洋, 植木幸明：中枢神経系の悪性リンパ腫。脳と神 27: 21-34, 1975

7) Lee YY, Bruner JM, Tassel PV, Libshitz HI: Primary central nervous system lymphoma; CT and pathologic correlation. AJR 147: 747-752, 1986

8) Letendre L, Banks PM, Reese DF, Miller RH, Scanlon PW, Kiely JM: Primary lymphoma of the central nervous system. Cancer 49: 939-943, 1982

9）西浦 㦑, 竹内重二, 半田 登, 姜 三錫: 頭蓋内悪性り ン八腫，腷神外科 $8: 839-844,1980$

10）脳腫場全国統計委員会：第一部 総論脳腫瘍の一般的事項 に関する集計，脳腫瘍全国集計調查報告，vol 6.1987，pp 9-42

11) Pagani JJ, Libshitz HI, Wallace $S$, Hayman LA: Central nervous system leukemia and lymphoma; computed tomographic manifestations. $A J R$ 137: 1195-1201, 1981

12) Poiesz BJ, Ruscetti FW, Gazdar AF, Bunn PA, Minna JD, Gallo RC: Detection and isolation of type $C$ retrovirus particles from fresh and cultured lymphocytes of a patient with cutaneous T-cell lymphoma. Proc Natl Acad Sci USA 77: 7415-7419, 1980

13) Schneck SA, Penn I: De-novo brain tumors in renal-transplant recipients. Lancet 1: 983-986, 1971

14) Scully RE, Mark EJ, McNeely BU: Case records of the Massachusetts General Hospital. Weekly clinicopathological exercises. $N$ Engl J Med 309: 359-369, 1983

15）田島和雄：ATL の疫学。豊島久真男, 高原 清(編)。図説 臨床(癌)シリーズ No. 9, ATL (成人 T 細胞白血病)。東京, メジカルビェー社, 1986, pp 62-71

16) Thomas $M$, MacPherson $P$ : Computed tomography of intracranial lymphoma. Clin Radiol 33: 331-336, 1982

17) Yoshida M, Miyoshi I, Hinuma $Y$ : Isolation and characterization of retrovirus from cell lines of human adult T-cell leukemia and its implication in the disease. Proc Nall Acad Sci USA 79:20312035,1982

18) Zimmerman HM: Malignant lymphomas of the nervous system. 脳と神 26: 1153-1170, 1974

〔別刷請求先：=920 金沢市石引3-1-1，国立金沢病院脳神経外 科, 池田正人] 